(c) American Dairy Science Association, 2006.

\title{
Absorption and Digestive Tract Metabolism of 2-Hydroxy-4- Methylthiobutanoic Acid in Lambs
}

\author{
G. E. Lobley, ${ }^{\star 1}$ T. J. Wester, ${ }^{\star 2}$ G. Holtrop,† J. J. Dibner,‡ D. S. Parker, $\ddagger$ and M. Vázquez-Añónł \\ ${ }^{*}$ Rowett Research Institute, Bucksburn, Aberdeen AB21 9SB, UK \\ †Biomathematics and Statistics Scotland, Rowett Research Institute, Bucksburn, Aberdeen, AB21 9SB, UK \\ $\ddagger$ Novus International, St. Louis, MO
}

\section{ABSTRACT}

Anabolic availability of the hydroxyl methionine analog, 2-hydroxy-4-methylthiobutanoic acid (HMTBA), given as oral doses to lambs, was quantified both directly as appearance in the portal vein and as synthesis to Met by digestive tract tissues. Eight lambs, prepared with vascular catheters in the mesenteric and portal veins plus the aorta, received twice daily for $7 \mathrm{~d}$ either $0.46 \mathrm{~g}$ or $2 \mathrm{~g}$ of HMTBA. On $\mathrm{d} 7,\left[1{ }^{13} \mathrm{C}\right] \mathrm{HMTBA}$ was supplied as 1 oral dose while [methyl- ${ }^{2} \mathrm{H}_{3}$ ] Met was infused into the jugular vein. Peak absorption as HMTBA occurred 70 to 90 min after the oral dose. All digestive tract tissues converted HMTBA to Met, equivalent to $24 \%$ of the Met provided by the diet for the larger HMTBA dose. Overall, total availability of HMBTA averaged $17.9 \%$ of the dose (range 10.6 to $27.9 \%$ ), with $12.5 \%$ (range 7 to $22 \%$ ) as absorbed HMBTA and the remainder as Met synthesized by digestive tract tissues. Release of ${ }^{13} \mathrm{CO}_{2}$ into the portal vein accounted for another $23 \%$ of the dose. In all digestive tract tissues, the D-isomer was present in a smaller proportion than in the dose. In terms of whole-body kinetics, HMTBA loss from the plasma followed first-order kinetics, with a mean biological half-life of $76 \mathrm{~min}$. Using this value, a simple model was devised to estimate HMTBA absorption based on peripheral plasma samples. When compared with direct measures of absorption, the model gave a slope of $0.81\left(R^{2}=0.68\right)$ and offers a practical means to test HMTBA availability to animals.

Key words: 2-hydroxy-4-methylthiobutanoic acid, digestive tract, lambs, absorption

\section{INTRODUCTION}

Previous studies have shown that absorbed DL-2-hydroxy-4-methylthiobutanoic acid (HMTBA; Alimet, No-

\footnotetext{
Received November 11, 2005.

Accepted April 25, 2006.

${ }^{1}$ Corresponding author: g.lobley@rowett.ac.uk

${ }^{2}$ Present address: Institute of Food, Nutrition \& Human Health, Massey University, PN 452, Private Bag 11 222, Palmerston North, New Zealand.
}

vus International Inc., St. Charles, MO) is converted to L-Met in most ruminant tissues (Lobley et al., 2006). Furthermore, more than $85 \%$ of a dose supplied to the abomasum is absorbed as HMTBA into the portal vein (Lobley et al., 2006) and provides an effective substitute for dietary Met (Lobley et al., 2006; Wester et al., 2006). There are losses associated with metabolism in the forestomachs, however, and these need to be considered when levels of commercial doses are set. For example, although HMTBA exhibits greater resistance to microbial degradation within the rumen compared with DLMet (Belasco, 1972; Patterson and Kung, 1988), only approximately $50 \%$ of various oral doses ( 25 to $90 \mathrm{~g} / \mathrm{d}$ ) of HMTBA was contained within the liquid phase of the rumen outflow from dairy cows (Koenig et al., 1999). Other studies have indicated that even less $(<6 \%)$ may reach the omasum (Noftsger et al., 2005). There may be several reasons for such losses. First, some HMTBA may be absorbed directly through the ruminal, omasal, or abomasal epithelia, as has been shown for the former 2 tissues in vitro (McCollum et al., 2000). Second, the forestomach tissues may convert the HMTBA to Met, as has been shown for tissues of the lower digestive tract (Lobley et al., 2006). Indeed, epithelial tissue from both the rumen and omasum contain high activities of the enzymes necessary to convert the $\mathrm{D}$ - and L-isomers of HMTBA to the L-Met precursor, oxo-Met (McCollum et al., 2000). Third, degradation of HMTBA by rumenderived microbes may continue during passage of fluid between the rumen and abomasum.

Some of these possibilities have been examined in the current series of studies, based on arteriovenous techniques across the digestive tract of sheep that have quantified direct absorption of oral doses of HMTBA into the portal vein. Furthermore, use of stable isotopes has allowed tracing of other metabolic fates of HMTBA within the digestive tract, notably quantification of oxidation of HMTBA and the conversion to Met. The latter is then partitioned between absorption and support of protein synthesis within the tissues of the digestive tract. In addition, these and earlier data (Lobley et al., 2006) allowed development of a simple method to 
estimate HMTBA absorption, based only on plasma sampling.

\section{MATERIALS AND METHODS}

\section{Animals and Diets}

Two separate groups, each of 4 wether Suffolk cross sheep, were prepared with silicone rubber catheters in the mesenteric, portal, and hepatic veins, plus aorta, as described previously (Lobley et al., 1995). The TMR was comprised of $50 \%$ grass hay, $30 \%$ barley, $9 \%$ fish meal, $10 \%$ molasses, and $1 \%$ vitamins and minerals (all as-fed, with estimated ME of $11.05 \mathrm{MJ} / \mathrm{kg}$ of DM, $23 \mathrm{~g}$ of N/kg of DM) and was offered at $837 \mathrm{~kJ} / \mathrm{kg}$ of $\mathrm{BW}^{0.75}$. This diet was calculated as adequate in Met to support growth of the lambs, based on net splanchnic appearance of Met for similar lambs on the same diet (Wester et al., 2006). For Experiment 1, the diet was offered as 2 equal meals ( 0800 and $2000 \mathrm{~h}$ ), but for Experiment 2 and the terminal study, the diet was supplied as 24 equal hourly portions. Water was freely available from buckets at all times. These sheep experiments were approved by the Ethical Review Committee of the Rowett Research Institute and conformed to UK legislation under the Animals (Scientific Procedures) Act 1986.

\section{Experiment 1: Absorption Studies}

The first 4 animals, average BW $58.2 \pm 4.4 \mathrm{~kg}$, were adjusted over $3 \mathrm{~d}$ to $0.46 \mathrm{~g}$ of HMTBA as Alimet twice daily $(0.016 \mathrm{~g} / \mathrm{kg}$ of BW per d; equivalent to approximately $10 \mathrm{~g} / \mathrm{d}$ for a 600-kg dairy cow), diluted with an equal volume of water, and dosed at the back of the throat by syringe just before each feed. On the fourth day, a mixture of $0.267 M$ p-amino hippurate ( $\mathbf{p A H}$, sodium salt), $0.05 M$ sodium phosphate buffer $\mathrm{pH} 7.4$, and heparin (700 IU/mL; Leo Laboratories, Princes Risborough, Herts, UK) was infused ( $15 \mathrm{~g} / \mathrm{h})$ into the mesenteric vein, starting $120 \mathrm{~min}$ before the morning feed. As the animals were fed they were also dosed with $0.46 \mathrm{~g}$ of $\left[1-{ }^{13} \mathrm{C}\right] \mathrm{HMTBA}$ (99 atom\% excess, containing $76 \%$ of monomer and synthesized by Novus International Inc.), similar to the previous days. Continuous 45-min blood samples (each $4 \mathrm{~mL}$ ) were withdrawn from the portal vein and artery by means of a peristaltic pump (Lobley et al., 1995) for the $8.25 \mathrm{~h}$ following dosing and feeding. Over the $7 \mathrm{~d}$ of HMTBA dosing, water intake was estimated from daily weighing of the water buckets.

\section{Experiment 2: Metabolic Studies}

The second 4 animals, average BW $49 \pm 2.9 \mathrm{~kg}$ (range 41 to $55 \mathrm{~kg}$ ), were used in a randomized cross-over design involving 2 treatments, either control (diet only for $7 \mathrm{~d}$ ) or HMTBA as Alimet (administered for $7 \mathrm{~d}$ ). The diet was supplied hourly as 24 equal portions by means of automated feeders. The dose of HMTBA was given twice daily at $0.042 \mathrm{~g} / \mathrm{kg}$ of BW (approximately $4 \mathrm{~g} / \mathrm{d}$, equivalent to $50 \mathrm{~g} / \mathrm{d}$ for a $600-\mathrm{kg}$ dairy cow), supplied as 2 equal portions at 0800 and $2000 \mathrm{~h}$. The morning dose was given at the back of the throat, similar to the absorption studies, and the evening dose was sprayed onto the appropriate feed portion in the automated feeders. From $0430 \mathrm{~h}$ on the seventh day of each period, a solution of $1 \mathrm{mmol} \mathrm{L}-\left[\right.$ methyl- $\left.{ }^{2} \mathrm{H}_{3}\right]$ Met $(99.2$ atom\% excess; MassTrace Inc., Woburn, MA), dissolved in $100 \mathrm{~g}$ of sterile $0.15 \mathrm{M} \mathrm{NaCl}$ was infused at $10 \mathrm{~g} / \mathrm{h}$ into the hepatic vein catheter. From 0600 h, a mixture of $0.10 \mathrm{MpAH}$ (sodium salt), $0.05 \mathrm{M}$ sodium phosphate buffer $\mathrm{pH} 7.4$, and heparin $(160 \mathrm{IU} / \mathrm{mL})$ was infused at a rate of $40 \mathrm{~g} / \mathrm{h}$ into the distal mesenteric vein catheter.

For the control period measurement, integrated blood samples (each $8.5 \mathrm{~mL}$ ) were taken continuously at hourly intervals from the arterial and portal vein catheters between 0800 and $1200 \mathrm{~h}$. For the HMTBA treatment period, a dose of $\left[1-{ }^{13} \mathrm{C}\right]$ HMTBA $(0.042 \mathrm{~g} / \mathrm{kg}$ of BW; 98.8 atom\% excess, with $72 \%$ as the monomer form, synthesized by Novus International Inc.) was given at $0800 \mathrm{~h}$ at the back of the throat immediately before the feed was offered, and continuous blood samples were collected hourly (each $10 \mathrm{~mL}$ ) for the next $6 \mathrm{~h}$ from the portal vein and aorta. On the previous day, triplicate background samples (each $4 \mathrm{~mL}$ ) had been taken at 30 min intervals from each of the 2 blood vessels for natural abundance measurements.

Terminal Study. This involved the same 4 sheep used in Experiment 2. For the pair treated in the order of control then HMBTA, this part of the study was conducted the day after administration of labeled HMTBA in the metabolic studies. The second pair, HMTBA then control, were readjusted to the normal dose of HMTBA (twice-daily $0.042 \mathrm{~g} / \mathrm{kg}$ of BW) for $5 \mathrm{~d}$. On the measurement day, a solution of $6.7 \mathrm{mM} \mathrm{L}$ [methyl- ${ }^{2} \mathrm{H}_{3}$ ] Met was prepared as for Experiment 2 (but containing $400 \mathrm{IU} / \mathrm{mL}$ heparin) and infused $(10 \mathrm{~g} / \mathrm{h})$ into the hepatic vein from $0430 \mathrm{~h}$. The sheep were then given a bolus dose of $\left[1-{ }^{13} \mathrm{C}\right] \mathrm{HMTBA}(0.042 \mathrm{~g} / \mathrm{kg}$ of BW) at $0800 \mathrm{~h}$ and then three 30-min continuous blood collections were taken from catheters in the artery, portal vein, and the proximal part of the mesenteric vein (each sample $6 \mathrm{~mL}$ ). At $90 \mathrm{~min}$ postdosing, the animals were killed by pentobarbitone overdose and samples of tissue (rumen, omasum, abomasum, duodenum, liver, kidney) were rapidly excised, washed free of digesta in ice-cold saline, frozen in liquid $\mathrm{N}$, and stored at $-80^{\circ} \mathrm{C}$. Rumen contents were chilled on ice water, strained through muslin, centrifuged $(7,200 \times g$ for $15 \mathrm{~min})$, and then 
frozen at $-20^{\circ} \mathrm{C}$. Dissection postmortem revealed that the tip of the catheter in the proximal mesenteric vein was at the junction with the gastro-splenic vein for 3 of the sheep. This meant that portal, rather than mesenteric, blood was sampled. In the other sheep, the catheter tip remained within the mesenteric vein.

\section{Analytical Techniques}

For the absorption study, blood was centrifuged at $1,000 \times g$ for $15 \mathrm{~min}$ at $4^{\circ} \mathrm{C}$ and the plasma isolated. Plasma flows were determined from downstream gravimetric dilution of $\mathrm{pAH}$, quantified as described previously (Lobley et al., 1995). Concentrations of HMTBA in plasma were determined by isotope dilution (Calder et al., 1999) as described previously (Wester et al., 2006), but with the internal standard as natural abundance calcium HMTBA (Fluka, Gillingham, Dorset, UK) because $\left[1-{ }^{13} \mathrm{C}\right]$ HMTBA was given as the metabolic tracer.

For the metabolic and terminal studies, triplicate 0.8$\mathrm{mL}$ samples of each integrated blood collection following the dose of $\left[1{ }^{13} \mathrm{C}\right] \mathrm{HMTBA}$ were injected onto frozen lactic acid in evacuated tubes for ${ }^{13} \mathrm{CO}_{2}$ analysis by gas isotope ratio mass spectrometry (Lobley et al., 2003, based on Read et al., 1984). Hemoglobin, pH, partial pressure of $\mathrm{O}_{2}\left(\mathbf{p O}_{2}\right)$, and partial pressure of $\mathrm{CO}_{2}$ $\left(\mathbf{p C O}_{2}\right)$ for blood samples were quantified using an ABL5 Blood Gas Monitor (Radiometer, Copenhagen, Denmark). The $\mathrm{pCO}_{2}$ measurement involves only the rapidly diffusible bicarbonate through the plasma compartment, and so total blood bicarbonate exchange was calculated based on this using standard gas equations (Sigaard-Anderson et al., 1988).

Part of the plasma was stored at $-20^{\circ} \mathrm{C}$ for later determination of $\left[1-{ }^{13} \mathrm{C}\right]$ and $\left[\right.$ methyl- $\left.{ }^{2} \mathrm{H}_{3}\right]$ Met enrichments (Lobley et al., 2006; Wester et al., 2006). To a further 0.8 -g portion of plasma was added a known amount $(0.3$ g) of an internal standard mixture of $100 \mu M\left[5-{ }^{13} \mathrm{C}\right]$ Met (99 atom\%, MassTrace Inc.) and $100 \mu M$ natural abundance calcium HMTBA (Fluka) for determination of Met and HMTBA concentrations by isotope dilution (Calder et al., 1999; Wester et al., 2006). For the control samples, the natural abundance calcium HMTBA was omitted from the internal standard mixture.

The tissues were ground in a freezer mill (Spex 6700, Glen Creston, Stanmore, UK) and then $1 \mathrm{~g}$ was weighed and homogenized in $3 \mathrm{~g}$ of $10 \mu M$ natural abundance calcium HMTBA, followed by addition of $0.8 \mathrm{~mL}$ of $48 \%$ (wt/vol) sulfosalicylic acid and centrifugation at 3,000 $\times g$ for $15 \mathrm{~min}$. The supernatant from this was used to measure both HMTBA concentrations and Met enrichments $\left(1-{ }^{13} \mathrm{C}\right.$ and methyl- $\left.-{ }^{2} \mathrm{H}_{3}\right)$. Another ground tissue portion was homogenized in water to estimate propor- tions of D- and L-HMTBA by gas chromatography-mass spectrometry after conversion to the heptafluorylbutyryl derivatives (Lobley et al., 2006). All Met enrichments (for both metabolic flows and concentration measurements) were quantified as the t-butyldimethylsilyl derivatives by electron impact gas-chromatography mass spectrometry. The $\mathrm{m} / \mathrm{z}$ ions $320,321,323$ corresponded to unlabeled, $\left[1-{ }^{13} \mathrm{C}\right]$, and $\left[{ }^{2} \mathrm{H}_{3}\right]$ forms. Where isotope dilution was performed using the same isotope already present in the plasma sample, as was the case with the metabolic studies, appropriate corrections were applied.

\section{Calculations}

Gravimetric plasma flow (as $\mathrm{kg} / \mathrm{min}$ ) was calculated from pAH dilution as described previously (Lobley et al., 1995). Net mass transfers ( $\mathrm{mmol} / \mathrm{min}$ ) across the mesenteric-drained viscera (MDV) and portal-drained viscera (PDV) were quantified from veno-arterial differences as follows:

$$
\mathrm{MDV}=(\mathrm{M}-\mathrm{A}) \times \mathrm{MF}
$$

and

$$
\mathrm{PDV}=(\mathrm{P}-\mathrm{A}) \times \mathrm{PF}
$$

where $\mathrm{A}, \mathrm{M}$, and $\mathrm{P}$ represent metabolite concentrations (Met, HMTBA, or $\mathrm{CO}_{2}$, as $\mathrm{m} M$ ) in arterial, mesenteric, or portal venous plasma, respectively, and $\mathrm{MF}$ and $\mathrm{PF}$ are gravimetric plasma flows $(\mathrm{kg} / \mathrm{min})$ in the mesenteric and portal veins, respectively. Values were calculated from individual analyses at each time point and these used to test for temporal responses.

Whole-body irreversible loss rate (WBILR, $\mathrm{mmol} / \mathrm{h}$ ) was derived from

$$
\mathrm{WBILR}=\left(99.2 / \mathrm{E}_{\mathrm{a}}-1\right) \times \mathrm{I}
$$

where 99.2 is the isotopic purity of the $\left[{ }^{2} \mathrm{H}_{3}\right]$ Met infused (as molar percent), $\mathrm{E}_{\mathrm{a}}$ is the enrichment (as molar percent excess, mpe) in the arterial sample, and I is the rate of infusion $(\mathrm{mmol} / \mathrm{h})$.

Isotope transfers ( $\mathrm{mmol} / \mathrm{h}$ ) across the PDV (or mesenteric drained viscera) were similar to the mass flow equations, namely

$$
=\left[\left(\mathrm{P} \times \mathrm{E}_{\mathrm{p} \text { or m }}\right)-\left(\mathrm{A} \times \mathrm{E}_{\mathrm{a}}\right)\right] \times \mathrm{PF}
$$

where $\mathrm{E}$ represents enrichment (mpe), the subscript refers to the vessel of origin (a, arterial; $\mathrm{m}$, mesenteric vein, or $p$, portal vein for measuring transfers across the MDV or PDV, respectively). For all data presented, 
mpe are expressed relative to the sum of the ion intensities of $\mathrm{m}+0, \mathrm{~m}+1$, and $\mathrm{m}+3$ above the appropriate natural abundance value.

These isotopic values could be converted into tissuebased irreversible loss rate by division by an appropriate precursor; that is, the enrichment of free Met in either the mesenteric or portal vein plasma.

\section{Tissue and Organ Conversion of HMTBA to Met}

The contribution of HMTBA to WBILR through the arterial plasma (mmol/time) was calculated from

WBILR (based on $\left.\left[{ }^{2} \mathrm{H}_{3}\right] \mathrm{Met}\right) \times \mathrm{E}_{\mathrm{a}}\left(\right.$ for $\left.\left[1-{ }^{13} \mathrm{C}\right] \mathrm{Met}\right) \times 0.01$.

Tissue conversions were determined by 2 approaches, both based on the principle (Lobley et al., 2006) that conversion of D- or L- $\left[1-{ }^{13} \mathrm{C}\right] \mathrm{HMTBA}$ will produce L-[1$\left.{ }^{13} \mathrm{C}\right]$ Met (Vázquez-Añón et al., 2001b) and this will alter the ratio of $\left[{ }^{13} \mathrm{C}\right]:\left[{ }^{2} \mathrm{H}_{3}\right]$ Met in either the tissue intracellular pool or the venous outflow relative to the arterial inflow. It is necessary to include comparison with $\left[{ }^{2} \mathrm{H}_{3}\right]$ Met rather than rely on changes in $\left[1-{ }^{13} \mathrm{C}\right]$ Met enrichment alone because the latter can be diluted by inflows of natural abundance Met (as released by protein turnover or absorbed from the diet). The resultant dilutions will affect both $\left[{ }^{13} \mathrm{C}\right]$ and $\left[{ }^{2} \mathrm{H}_{3}\right]$ Met similarly, but not alter the ratio of $\left[1-{ }^{13} \mathrm{C}\right]:\left[{ }^{2} \mathrm{H}_{3}\right]$ Met. On the other hand, if HMTBA were converted to Met within a studied tissue then the ratio of $\left[1-{ }^{13} \mathrm{C}\right]:\left[{ }^{2} \mathrm{H}_{3}\right]$ Met would be greater than for the artery. If any of this synthesized Met were exported from the tissue then the ratio in the vein would also exceed that in the artery.

Tissue Synthesis of Met from HMTBA. This follows the approach described previously (Lobley et al., 2006) and involves calculation based on ratios of $\left[{ }^{13} \mathrm{C}\right]:\left[{ }^{2} \mathrm{H}_{3}\right]$ Met enrichments in the tissue and the arterial plasma. The proportion of Met synthesis from HMTBA in situ (S) to HMTBA-derived Met transported (T) into the tissue following synthesis elsewhere in the body was obtained from the equation:

$$
1-x=\mathrm{Rp} / \mathrm{Rt}
$$

where $x$ represents $\mathrm{S} /(\mathrm{S}+\mathrm{T})$ and $\mathrm{R}$ is the [1$\left.{ }^{13} \mathrm{C}\right]:\left[{ }^{2} \mathrm{H}_{3}\right]$ Met ratio in either arterial plasma $(\mathrm{p})$ or the tissue ( $\mathrm{t}$ ) free pool. This yields a minimum value for $\mathrm{S} /$ $(\mathrm{S}+\mathrm{T})$, as this assumes that all arterial inflow exchanges with the tissue intracellular pool.

Kinetic Model. The double-label approach described above can be incorporated into a transorgan model extended from the principles described by Biolo et al. (1995). The model for Met kinetics assumes that all intracellular events flow through a common pool and derives inward and outward transport, arterial bypass, protein synthesis and degradation, plus synthesis de novo. Based on the assumption that all isotopic species of Met are treated similarly by the body, the status of $\left[1-{ }^{13} \mathrm{C}\right]$ Met in a tissue (or venous drainage) can be predicted from $\left[{ }^{2} \mathrm{H}_{3}\right]$ Met kinetics in the absence of any synthesis in situ from $\left[1-{ }^{13} \mathrm{C}\right]$ HMTBA. This prediction is then compared with observed $\left[1-{ }^{13} \mathrm{C}\right]$ Met enrichments and, by difference, the amount synthesized in situ (from $\left[1-{ }^{13} \mathrm{C}\right]$ HMTBA) quantified. The model assumes that both a metabolic and isotopic steady state are achieved. These assumptions are reasonable with the adoption of a frequent feeding regimen and continuous infusion of $\left[{ }^{2} \mathrm{H}_{3}\right]$ Met. In the current study, the HMTBA was supplied as a bolus dose and thus nonsteady-state conditions apply, but a prediction of HMTBA metabolism at the time of slaughter, involving removal of digestive tract tissue for analysis, can be obtained. This model, with appropriate equations, is presented in the Appendix.

\section{Indirect Estimation of HMTBA Absorption}

2-Hydroxy-4-methylthiobutanoic acid only exists in negligible quantities naturally in the body (plasma concentrations less than $0.2 \mu M$ in the control sheep in the current study, for example) and, therefore, any pool of HMTBA in the body must be derived from exogenous supply. If HMTBA enters cells mainly by diffusion (Dibner et al., 1988) it will be present in many tissues at concentrations similar to that in plasma (Lobley et al., 2006). Then, analogous to the situation with urea, the total HMTBA pool size (denoted by q, $\mu \mathrm{mol}$ ) can be represented by body water multiplied by plasma HMTBA concentrations, where body water is set at 0.66 of BW.

It is also assumed that the loss of HMTBA from the body pool (through conversion to Met and oxidation) follows first order kinetics at a rate equal to $\mathrm{k} \times \mathrm{q}$, where $\mathrm{k}\left(\mathrm{min}^{-1}\right)$ is the rate constant. Based on inspection of the data, it is further assumed that absorption will have ceased $270 \mathrm{~min}$ after administration of the bolus dose, so that changes in the HMTBA body pool thereafter solely reflect losses. Based on these assumptions, $\mathrm{k}$ can be estimated from regression of $\ln (q)$ on time, where only the last 3 (Experiment 2) or last 5 (Experiment 1) samples are used.

Absorption is then calculated based on the principle that changes in plasma HMTBA concentration following an oral (or intestinal) dose will reflect the balance between total body water HMTBA inflow (absorption) and outflow (conversion to Met and oxidation). Then absorption over any time interval $\left(t_{1}, t_{2}\right)$ can be calculated as follows: 


$$
\operatorname{Absorption}\left(t_{1}, t_{2}\right)=q\left(t_{2}\right)-q\left(t_{1}\right)+\operatorname{outflow}\left(t_{1}, t_{2}\right)
$$

where

$$
\operatorname{outflow}\left(\mathrm{t}_{1}, \mathrm{t}_{2}\right)=\mathrm{k} \times 0.5 \times\left[\mathrm{q}\left(\mathrm{t}_{1}\right)+\mathrm{q}\left(\mathrm{t}_{2}\right)\right] \text {. }
$$

An alternative, but mathematically equivalent, approach is that over infinite time all outflow will equal inflow (absorption) and the former can be determined from $\mathrm{k}$ and pool size extrapolated to infinite time. For both approaches, plasma samples are taken during the absorptive and postabsorptive phases for HMTBA. These values can be adjusted for the first-pass removal of HMTBA by the liver and that will lower the amount available to posthepatic body water pools. From studies on sheep under similar conditions the hepatic extraction amount to $4 \%$ of the total HMTBA inflow to the liver (Wester et al., 2006).

\section{Statistical Analyses}

Data were analyzed using GenStat seventh edition, release 7.2 (VSN International Ltd., Hemel Hempstead, Herts, UK). One-way ANOVA was applied with animals treated as random effects and treatments as fixed effects. For Experiment 1, the effect of both time and blood vessel site were also compared with random terms for animal, time interval within animal (repeated measures), and site within animal plus interactions of these terms. Fixed effects were blood vessel and time, plus their interaction. Where the ANOVA revealed significant treatment effects, individual treatments were compared further based on a posthoc $t$-test.

\section{RESULTS}

\section{Absorption of HMTBA}

All animals successfully completed the trials with the only problem being the positioning of the mesenteric vein catheters, as already mentioned. Neither Alimet nor $\left[{ }^{13} \mathrm{C}\right]$ HMTBA provision altered the plasma flow in the portal vein (data not shown).

Although different animals were used for the low and moderate HMTBA doses $(0.016$ and $0.084 \mathrm{~g} / \mathrm{kg}$ of BW per d) used in Experiments 1 and 2, the temporal responses in HMTBA appearance in the portal vein were similar (Figure 1; see also Table 1). Peak absorption occurred between 70 to $90 \mathrm{~min}$, but use of integrated blood samples prevented finer definition. In both studies there was considerable variation between the animals in the proportion of HMTBA absorbed, but in all cases absorption was complete within $360 \mathrm{~min}$. For the lower dose, average recovery of HMTBA in the portal

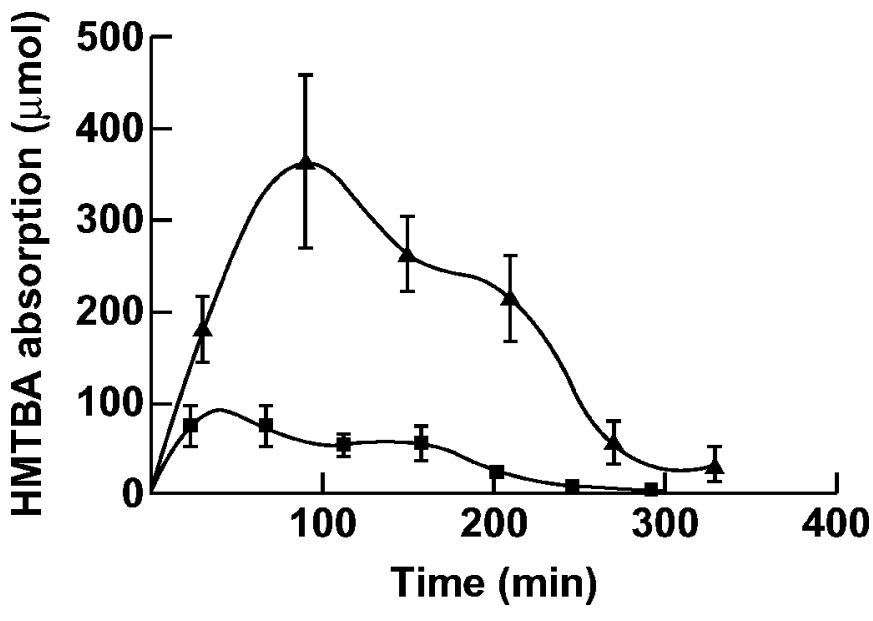

Figure 1. Net appearance (absorption) of DL-2-hydroxy-4-methylthiobutanoic acid (HMTBA) in the portal vein following oral doses into 4 sheep at either $0.46[\mathbf{\square}]$ or $2 \mathrm{~g}[\mathbf{\Delta}]$ per dose.

vein was $13 \%$, with a range of 7 to $18 \%$; at the higher dose the mean recovery (12.5\%) was similar (Table 1 ), with, again, a spread among sheep (9 to 22\%). At the higher dose of HMTBA, the lowest recovery was observed for a sheep drinking $2.8 \mathrm{~L} / \mathrm{d}$ of water, whereas the animal with the highest recovery drank $4.9 \mathrm{~L} / \mathrm{d}$.

These direct measures of HMTBA absorption into the portal vein were then used to test the less invasive approach based on concentrations in peripheral plasma. The natural logarithm of arterial plasma concentrations plotted against time following the lower oral dose for the 4 sheep in Experiment 1 are shown in Figure 2. For all sheep this showed a good fit with first-order kinetics over the later time points (i.e., after absorption of HMTBA had ceased), allowing derivation of the rate constant, $\mathrm{k}$, for the fractional removal of HMTBA from the plasma. The mean value for $\mathrm{k}$ was $0.0092 / \mathrm{min}$ (standard deviation 0.0028), with a corresponding half-life of $76 \mathrm{~min}$. The agreement between direct absorption and the indirect estimate based on plasma concentrations is shown in Figure 3. The linear regression equation had a gradient of 0.81 and an $R^{2}$ of 0.68 . The fit was poorer $\left(R^{2}=0.45\right)$ if the intercept was driven through zero, but the slope was close to unity $(1.19, \mathrm{SEM}=0.16)$.

\section{Metabolic Studies}

Whole Body Metabolism. At the dose used in Experiment 2 the arterial plasma Met concentration of the sheep increased (by a maximum of $19 \%, P<0.006$ ) in the 1 to $4 \mathrm{~h}$ following administration of HMTBA (Table 1). Despite this, there were no differences in average arterial Met concentration between control and 
Table 1. Temporal concentrations in the arterial (A) and portal (P) plasma and net appearances across the portal-drained viscera (PDV) of DL-2-hydroxy-4-methylthiobutanoic acid (HMTBA), Met, and labeled ${ }^{13} \mathrm{CO}_{2}$ of 4 lambs given a $0.042 \mathrm{~g} / \mathrm{kg}$ of BW (total $9.4 \mathrm{mmol}$ ) bolus dose of $\left[1-{ }^{13} \mathrm{C}\right] \mathrm{HMTBA}$ and infused for $9.5 \mathrm{~h}$ with $\left[\right.$ methyl- $\left.{ }^{2} \mathrm{H}_{3}\right] \mathrm{Met}(1.7 \mu \mathrm{mol} / \mathrm{min})$ into a jugular vein

\begin{tabular}{|c|c|c|c|c|c|c|c|c|}
\hline \multirow[b]{2}{*}{ Time (min) } & \multirow{2}{*}{$\begin{array}{l}\text { Plasma flow } \\
(\mathrm{kg} / \mathrm{min})\end{array}$} & \multicolumn{2}{|c|}{ HMTBA $(\mu M)$} & \multicolumn{2}{|c|}{$\operatorname{Met}(\mu M)$} & \multicolumn{3}{|c|}{ Net PDV fluxes $(\mu \mathrm{mol} / \mathrm{h})$} \\
\hline & & $\mathrm{A}$ & $\mathrm{P}$ & $\mathrm{A}$ & $\mathrm{P}$ & HMTBA & Met & ${ }^{13} \mathrm{CO}_{2}$ \\
\hline 0 to 60 & 1.67 & $3.9^{\mathrm{a}}$ & $5.9^{\mathrm{a}}$ & $34.6^{\mathrm{ab}}$ & $40.6^{\mathrm{ab}}$ & $182^{\text {abc }}$ & 578 & $313^{\mathrm{ab}}$ \\
\hline 120 to 180 & 1.45 & $23.5^{\mathrm{d}}$ & $26.9^{\mathrm{d}}$ & $38.7^{\mathrm{bc}}$ & $46.0^{\mathrm{ab}}$ & $264^{\text {cd }}$ & 601 & $396^{\mathrm{ab}}$ \\
\hline 180 to 240 & 1.66 & $21.4^{\text {cd }}$ & $23.7^{\text {cd }}$ & $41.0^{\mathrm{c}}$ & $47.8^{\mathrm{b}}$ & $216^{\text {bcd }}$ & 685 & $389^{\mathrm{ab}}$ \\
\hline 240 to 300 & 1.50 & $16.1^{\mathrm{bc}}$ & $16.7^{\mathrm{bc}}$ & $34.9^{\mathrm{ab}}$ & $41.2^{\mathrm{ab}}$ & $57^{\mathrm{ab}}$ & 574 & $282^{\mathrm{a}}$ \\
\hline 300 to 360 & 1.52 & $11.0^{\mathrm{b}}$ & $11.4^{\mathrm{ab}}$ & $32.6^{\mathrm{a}}$ & $38.5^{\mathrm{a}}$ & $32^{\mathrm{a}}$ & 535 & $155^{\mathrm{a}}$ \\
\hline$\%$ dose & & & & & & 12.5 & & 22.6 \\
\hline Net absorption, $\mu \mathrm{mol}( \pm \mathrm{SEM})$ & & & & & & & 1,115 & \\
\hline Net absorption/dose, \% ( \pm SEM $)$ & & & & & & & $12.5(3.0)$ & \\
\hline
\end{tabular}

${ }^{\mathrm{a}-\mathrm{c}}$ Values within the same column with unlike superscripts are significantly different $(P<0.01)$, by posthoc $t$-test.

${ }^{1}$ By ANOVA, with animals treated as a random effect and with time as a fixed effect, within each column, 15 residual degrees of freedom.

HMTBA treatments (35.0 vs. $36.9 \mu M$, SEM 1.0) over the $6 \mathrm{~h}$ of measurement. Similarly, WBILR of Met (based on $\left[{ }^{2} \mathrm{H}_{3}\right]$ Met kinetics) was not different between control and HMTBA periods (1.79 vs. $1.81 \mathrm{mmol} / \mathrm{h}$, SEM $=0.08$. Nonetheless, following HMTBA dosing, the $\left[1-{ }^{13} \mathrm{C}\right]$ Met enrichments did increase with time $(P$ $<0.001$ ) and reached a maximum during the third hour of blood collection, at which time this accounted for $8.9 \%$ of arterial Met (Table 2). Over the $6 \mathrm{~h}$ of measurement, the HMTBA dose contributed $6.1 \%$ toward wholebody plasma Met flux.

HMTBA Metabolism by the Digestive Tract. Plasma flows and arterial and portal vein concentrations of HMTBA and Met for the $6 \mathrm{~h}$ following administration of HMTBA in Experiment 2 are shown in Table

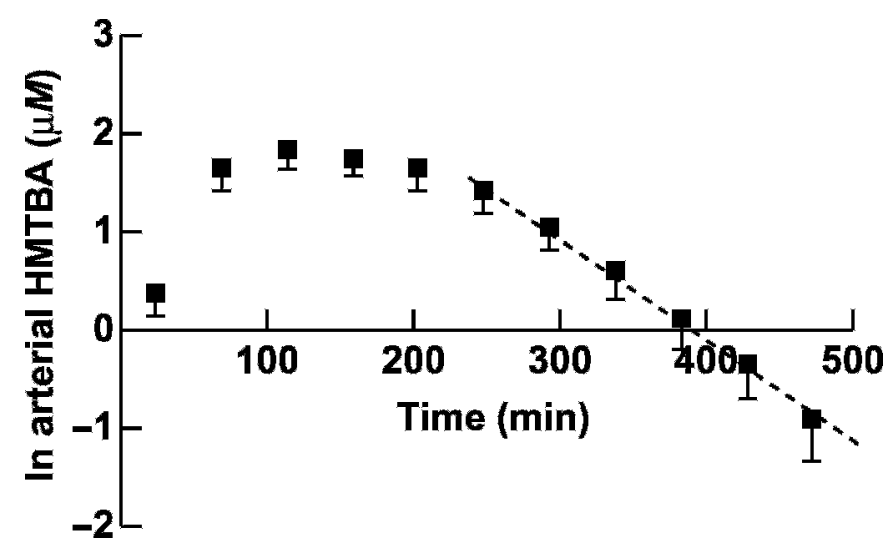

Figure 2. Seminatural logarithm plot of arterial DL-2-hydroxy-4methylthiobutanoic acid (HMTBA) concentration with time following an oral dose of $0.46 \mathrm{~g}$ of HMTBA into lambs. The dotted line represents the linear equation to fit the decline in arterial HMTBA concentration after absorption has finished. The rate constant, $\mathrm{k}$, for this line was $0.55 / \mathrm{h}$, equal to a biological half-life of HMTBA of $76 \mathrm{~min}$.
1. There were no differences in plasma flow during the measurement period, as expected for animals maintained on a frequent feeding regimen. Despite the increases in arterial Met concentrations mentioned above, there was no effect of time on net Met absorption. Furthermore, there were no differences in net Met absorption between control and HMTBA treatments (774 vs. $597 \mu \mathrm{mol} / \mathrm{h}, \mathrm{SEM}=89$ ). Following the HMTBA dose, the increase and subsequent decrease in HMTBA absorption $(P<0.001)$ was reflected as corresponding changes of both arterial and portal plasma HMTBA concentrations $(P<0.001)$.



Figure 3. Comparison of estimates of DL-2-hydroxy-4-methylthiobutanoic acid (HMTBA) absorption by the portal drained viscera (PDV), determined indirectly from arterial plasma concentrations and the rate constant, $\mathrm{k}$, shown in Figure 2 with direct measures of absorption from arteriovenous uptake into the portal vein of 8 sheep, fed either 0.46 or $2.0 \mathrm{~g}$ doses of HMTBA. The indirect calculations include a correction of $4 \%$ to allow for first pass extraction of HMTBA by the liver prior to mixing with the body water pool (Wester et al., 2006). The solid line gives the equation for the best fit line, $y=0.81$ $( \pm 0.23) x+503( \pm 242), R^{2}=0.68$, and the dotted line is for the equation driven through the origin, $\mathrm{y}=1.19( \pm 0.16) \mathrm{x}, \mathrm{R}^{2}=0.45$. 
Table 2. Temporal changes in $\left[1-{ }^{13} \mathrm{C}\right]$ and $\left[{ }^{2} \mathrm{H}_{3}\right]$ Met enrichments (molar percent excess, mpe) in the arterial (A) and portal (P) plasma plus net $\left[{ }^{13} \mathrm{C}\right]$ Met appearances across the portal-drained viscera (PDV) in 4 lambs following a $0.042 \mathrm{~g} / \mathrm{kg}$ BW oral bolus dose of $\left[1{ }^{13} \mathrm{C}\right]$ DL-2-hydroxy-4-methylthiobutanoic acid (HMTBA) and continuous infusion for $9.5 \mathrm{~h}$ of $\left[\right.$ methyl- $\left.{ }^{2} \mathrm{H}_{3}\right] \mathrm{Met}(1.7 \mu \mathrm{mol} / \mathrm{min})$ into a jugular vein

\begin{tabular}{|c|c|c|c|c|c|c|c|c|}
\hline \multirow[b]{2}{*}{ Time $(\min )$} & \multicolumn{2}{|c|}{$\underline{\left[1-^{13} \mathrm{C}\right] \text { Met mpe }}$} & \multicolumn{2}{|c|}{$\underline{\left[{ }^{2} \mathrm{H}_{3}\right] \text { Met mpe }}$} & \multicolumn{2}{|c|}{$\left[1-{ }^{13} \mathrm{C}\right]:\left[{ }^{2} \mathrm{H}_{3}\right]$ Met } & \multirow{2}{*}{$\begin{array}{l}\text { Net }\left[{ }^{13} \mathrm{C}\right] \mathrm{Met} \\
\text { across PDV } \\
\mu \mathrm{mol} / \mathrm{h}\end{array}$} & \multirow{2}{*}{$\begin{array}{l}\% \text { Met from } \\
\text { HMTBA }\end{array}$} \\
\hline & $\mathrm{A}$ & $\mathrm{P}$ & $\mathrm{A}$ & $\mathrm{P}$ & $\mathrm{A}$ & $\mathrm{P}$ & & \\
\hline 0 to 60 & $1.70^{\mathrm{a}}$ & $1.52^{\mathrm{a}}$ & 5.51 & 3.93 & $0.31^{\mathrm{a}}$ & $0.39^{\mathrm{a}}$ & 13.1 & 2.5 \\
\hline 60 to 120 & $7.32^{\mathrm{bc}}$ & $5.97^{\mathrm{bc}}$ & 5.20 & 3.66 & $1.49^{\mathrm{bc}}$ & $1.70^{\mathrm{bc}}$ & 35.6 & 7.8 \\
\hline 120 to 180 & $8.89^{\mathrm{c}}$ & $7.42^{\mathrm{c}}$ & 5.71 & 3.72 & $1.70^{\mathrm{bc}}$ & $2.07^{\mathrm{c}}$ & 70.3 & 11.1 \\
\hline 180 to 240 & $8.07^{\mathrm{c}}$ & $6.57^{\mathrm{c}}$ & 5.05 & 3.46 & $1.73^{\mathrm{c}}$ & $1.91^{\mathrm{c}}$ & 40.5 & 5.1 \\
\hline 240 to 300 & $6.32^{\mathrm{bc}}$ & $5.30^{\mathrm{bc}}$ & 5.59 & 3.86 & $1.23^{\mathrm{bc}}$ & $1.42^{\mathrm{bc}}$ & 38.8 & 6.8 \\
\hline 300 to 360 & $4.49^{\mathrm{ab}}$ & $3.60^{\mathrm{ab}}$ & 5.62 & 3.90 & $0.82^{\mathrm{ab}}$ & $0.96^{\mathrm{ab}}$ & 22.7 & 4.5 \\
\hline \multicolumn{9}{|l|}{ Effect of time } \\
\hline $\mathrm{SED}^{1}$ & 1.17 & 0.82 & 0.319 & 0.172 & 0.302 & 0.277 & 23.7 & 3.24 \\
\hline$P^{1}$ & 0.001 & 0.001 & NS & NS & 0.002 & 0.001 & NS & NS \\
\hline \multicolumn{9}{|l|}{ Effect of sample site } \\
\hline $\mathrm{SED}^{2}$ & 0.375 & & 0.295 & & 0.035 & & & \\
\hline$P^{2}$ & 0.067 & & 0.011 & & 0.011 & & & \\
\hline
\end{tabular}

${ }^{\mathrm{a}-c}$ Values within the same column with unlike superscripts are significantly different $(P<0.01)$, by posthoc $t$-test.

${ }^{1}$ By ANOVA, with animals treated as a random effect and time as a fixed effect within each column, 15 residual degrees of freedom.

${ }^{2}$ By ANOVA, with animal, time within animal, site within animal, and their interaction and with time and sample site, i.e., arterial vs. portal plasma, as fixed effects for each labeled form of Met, 3 residual degrees of freedom. For $\left[1-{ }^{13} \mathrm{C}\right]$ Met mpe there was a sample site by time interaction (standard error of the difference $0.452, P=0.032,15$ residual degrees of freedom).

The release of labeled ${ }^{13} \mathrm{CO}_{2}$ across the PDV exhibited a similar temporal pattern to HMTBA absorption with greatest oxidation observed between 1 and $2 \mathrm{~h}$ postdose (Table 1). Most, but not all, of the oxidation was complete by $6 \mathrm{~h}$ postdose. The proportion of dose recovered as ${ }^{13} \mathrm{CO}_{2}$ was $22.6 \%$ (range 19.1 to $26.5 \%$ ). During the terminal procedure, the bicarbonate enrichments in mesenteric vein blood (one sheep only) were identical to those in arterial blood (both averaged 1.1463 atom\%), but less $(P<0.01)$ than in the corresponding samples from the portal vein (1.1571 atom\%). These limited data suggest that the digestive tract oxidation of HMTBA (or products) is probably prior to the small intestine.

Based on data for $\mathrm{CO}_{2}$ production in animals of similar size and intake (Lobley et al., 2003), plus the enrichment increases for arterial plasma bicarbonate, the predicted estimates of whole body oxidation were $60 \%$ (range 54.8 to $62.8 \%$ ) of the dose. This compares with the $22.6 \%$ of the dose oxidized across the digestive tract tissues. Thus, the majority of the oxidation of HMTBA (plus derived Met or other metabolites) occurred in nonPDV tissues.

Enrichments of $\left[{ }^{2} \mathrm{H}_{3}\right]$ Met in the portal vein were always lower than in the artery $(P=0.011$, Table 2$)$, indicative of absorption of unlabeled Met plus release from tissue protein breakdown. The enrichment of plasma $\left[1-{ }^{13} \mathrm{C}\right]$ Met also tended to decrease across the $\operatorname{PDV}(P=0.067)$, with a time by blood vessel interaction $(P=0.032)$. Overall, the ratio of $\left[1-{ }^{13} \mathrm{C}\right]:\left[{ }^{2} \mathrm{H}_{3}\right]$ Met increased between the arterial inflow and venous outflow
$(P=0.011$, Table 2$)$. This indicated that Met was synthesized from HMTBA by either the tissues or microbes of the digestive tract and then absorbed.

Terminal Study. At 90 min postdosing, the concentrations of HMTBA were similar in tissue from the omasum, abomasum, and duodenum (Table 3), but all were larger $(P<0.05)$ than the values for liver, kidney, and rumen epithelium (which were not significantly different from each other). The concentration of HMTBA in the rumen epithelium was less than $4 \%$ that in the ruminal fluid $(465 \mu \mathrm{mol} / \mathrm{kg}$ of fluid, range 304 to 687) at the time of slaughter. There were also differences between tissues in the proportions of D- and L-isomer present. Thus, HMTBA in abomasal tissue was 35\% D-isomer compared with less than 30\% for rumen and duodenum tissues $(P<0.05$; Table 3$)$. In contrast, for arterial plasma, the D-isomer comprised only $19 \%$ of HMTBA, but this increased to $24 \%(P<$ 0.01 ) in the portal vein (Table 3 ). Although the dose of HMTBA contained D- and L-isomers in equimolar proportions (0.49:0.51), by $90 \mathrm{~min}$ after dosing the HMTBA remaining in the rumen liquor contained a smaller proportion $(P<0.001)$ of the L-isomer (average 0.29 ; range 0.14 to 0.42 ).

Although all tissues contained $\left[1-{ }^{13} \mathrm{C}\right]$ Met (derived from $\left[1-{ }^{13} \mathrm{C}\right]$ HMTBA $)$, the enrichments were lower $(P<$ 0.001) than those for arterial plasma, except for the kidney where the enrichment was greater $(P<0.001$; Table 4). Similarly, all tissue $\left[{ }^{2} \mathrm{H}_{3}\right]$ Met enrichments (including kidney) were considerably lower $(P<0.001)$ 
Table 3. Concentrations of DL-2-hydroxy-4-methylthiobutanoic acid (HMTBA) and proportions of D- and L-isomer in sheep tissues 90 min after an oral dose of $0.042 \mathrm{~g} / \mathrm{kg}$ of BW $\left[1{ }^{13} \mathrm{C}\right] \mathrm{HMTBA}$ and $4-\mathrm{h}$ continuous infusion of [methyl- ${ }^{2} \mathrm{H}_{3}$ ] Met $(1.1 \mu \mathrm{mol} / \mathrm{min})$ into the jugular vein in 4 lambs

\begin{tabular}{llll}
\hline Tissue & $\begin{array}{l}\text { HMTBA } \\
\text { concentration } \\
(\mu \mathrm{mol} / \mathrm{kg})\end{array}$ & $\begin{array}{l}\text { D-HMTBA } \\
\text { (\% of total } \\
\text { HMTBA })\end{array}$ & $\begin{array}{l}\text { L-HMTBA } \\
(\% \text { of total } \\
\text { HMTBA })\end{array}$ \\
\hline Rumen $^{1}$ & $18.5^{\mathrm{a}}$ & $27.1^{\mathrm{a}}$ & $72.9^{\mathrm{a}}$ \\
Omasum & $47.3^{\mathrm{b}}$ & $31.2^{\mathrm{ab}}$ & $68.8^{\mathrm{ab}}$ \\
Abomasum & $54.8^{\mathrm{b}}$ & $35.2^{\mathrm{b}}$ & $64.8^{\mathrm{b}}$ \\
Duodenum & $42.4^{\mathrm{b}}$ & $28.6^{\mathrm{a}}$ & $71.3^{\mathrm{a}}$ \\
Liver & $8.3^{\mathrm{a}}$ & $\mathrm{ND}^{2}$ & $\mathrm{ND}$ \\
Kidney & $20.3^{\mathrm{a}}$ & $\mathrm{ND}$ & $\mathrm{ND}$ \\
SED & 8.8 & 2.41 & 2.41 \\
$P^{3}$ & 0.001 & 0.05 & 0.05 \\
Arterial plasma & $\mathrm{ND}$ & $19.5^{\mathrm{A}}$ & $80.5^{\mathrm{A}}$ \\
Portal plasma & $\mathrm{ND}$ & $23.8^{\mathrm{B}}$ & $76.2^{\mathrm{B}}$ \\
SED & - & 0.72 & 0.72 \\
$P^{4}$ & - & $<0.01$ & $<0.01$ \\
\hline
\end{tabular}

${ }^{1}$ Corresponding values for rumen liquor were total HMTBA $=465$ $\mu \mathrm{M}, \mathrm{D}-\mathrm{HMTBA}=28.6 \%, \mathrm{~L}-\mathrm{HMTBA}=71.4 \%$.

${ }^{2} \mathrm{ND}=$ Not determined.

${ }^{3}$ By ANOVA, with animals as random effects and comparisons between tissues as fixed effects, 15 residual degrees of freedom. Values within the same column with unlike superscripts (a, b) are significantly different $(P<0.05)$ by posthoc $t$-test.

${ }^{4}$ By ANOVA with animals as a random effect and blood vessel site (i.e., arterial vs. portal plasma) as a fixed effect, 3 residual degrees of freedom. Values within the same column with unlike superscripts (A, B) are significantly different $(P<0.01)$, by posthoc $t$-test.

than for arterial plasma. The ratio of enrichments for $\left[1{ }^{13} \mathrm{C}\right]:\left[{ }^{2} \mathrm{H}_{3}\right]$ Met was greater $(P<0.001)$ in all tissues compared with arterial plasma (Table 4 ) with the ratio in kidney higher than for all other tissues $(P<0.001)$. The $\left[1{ }^{13} \mathrm{C}\right]:\left[{ }^{2} \mathrm{H}_{3}\right]$ ratios were similar across the splanchnic tissues except for lower values for the duodenum $(P<0.05)$. The ratio of $\left[1-{ }^{13} \mathrm{C}\right]:\left[{ }^{2} \mathrm{H}_{3}\right]$ Met was used to derive the minimum contribution of Met synthesized from HMTBA in situ compared with total HMTBAderived Met inflow into the cells (the sum of inward transport from plasma plus that synthesized in situ from HMTBA; Table 4). The largest fractional contribution occurred in the kidney $(0.27 ; P<0.001$, compared with other tissues). For the digestive tract tissues, the proportion from synthesis in situ ranged from 0.08 to 0.12 , with omasum higher than duodenum $(P<0.01)$.

The isotope data, obtained from the terminal study and mass transfers from Experiment 2, and conducted on the same animals within 1 to $7 \mathrm{~d}$ of each other under similar dietary and experimental conditions, were used to produce the kinetic model illustrated in Figure 4. The $\left[1-{ }^{13} \mathrm{C}\right]:\left[{ }^{2} \mathrm{H}_{3}\right]$ Met ratios for the 4 digestive tract tissues (see Table 4) were averaged to give a composite value for the whole gut. This model allows a better description of the amount of Met synthesized within the cells of the digestive tract and exported compared with that used to support intracellular protein synthe-
Table 4. Tissue free $\left[{ }^{13} \mathrm{C}\right]$ and $\left[{ }^{2} \mathrm{H}_{3}\right]$ Met enrichments (molar percent excess, mpe) 90 -min post oral dosing of $0.042 \mathrm{~g} / \mathrm{kg}$ of BW $\left[1-{ }^{13} \mathrm{C}\right] \mathrm{DL}-$ 2-hydroxy-4-methylthiobutanoic acid (HMTBA) and 4-h continuous infusion of $\left[\right.$ methyl- $\left.{ }^{2} \mathrm{H}_{3}\right]$ Met $(1.1 \mu \mathrm{mol} / \mathrm{min})$ into jugular vein in 4 lambs

\begin{tabular}{|c|c|c|c|c|}
\hline & \multicolumn{3}{|c|}{ Met enrichments (mpe) } & \multirow{2}{*}{$\begin{array}{l}\% \text { Intracellular } \\
\text { Met from } \\
\text { HMTBA }^{1}\end{array}$} \\
\hline & ${ }^{13} \mathrm{C}$ & ${ }^{2} \mathrm{H}_{3}$ & ${ }^{13} \mathrm{C}:{ }^{2} \mathrm{H}_{3}$ & \\
\hline Rumen & $4.65^{\mathrm{b}}$ & $0.96^{\mathrm{b}}$ & $4.91^{\mathrm{ab}}$ & $10.4^{\mathrm{a}, \mathrm{AB}}$ \\
\hline Omasum & $5.15^{\mathrm{ab}}$ & $0.91^{\mathrm{b}}$ & $5.41^{\mathrm{ab}}$ & $12.0^{\mathrm{a}, \mathrm{A}}$ \\
\hline Abomasum & $6.18^{\mathrm{ab}}$ & $1.32^{\mathrm{a}}$ & $4.61^{\mathrm{ab}}$ & $9.6^{\mathrm{a}, \mathrm{AB}}$ \\
\hline Duodenum & $3.88^{\mathrm{b}}$ & $0.94^{\mathrm{b}}$ & $4.13^{\mathrm{ab}}$ & $8.1^{\mathrm{a}, \mathrm{B}}$ \\
\hline Liver & $4.69^{b}$ & $0.68^{\mathrm{c}}$ & $6.91^{\mathrm{ab}}$ & $9.0^{\mathrm{a}}$ \\
\hline Kidney & $11.04^{\mathrm{c}}$ & $0.93^{\mathrm{b}}$ & $12.45^{\mathrm{c}}$ & $27.1^{\mathrm{b}}$ \\
\hline Arterial plasma & $6.70^{\mathrm{a}}$ & $3.73^{\mathrm{d}}$ & $1.76^{\mathrm{d}}$ & - \\
\hline $\mathrm{SED}^{2}$ & 0.908 & 0.135 & 1.313 & 2.79 \\
\hline$P^{2}$ & $<0.001$ & $<0.001$ & $<0.001$ & $<0.001$ \\
\hline $\mathrm{SED}^{3}$ & - & - & - & 0.95 \\
\hline$P^{3}$ & - & - & - & 0.017 \\
\hline
\end{tabular}

${ }^{1}$ Calculations based on ratio of $\left[1-{ }^{13} \mathrm{C}\right]:\left[{ }^{2} \mathrm{H}_{3}\right]$ Met in tissue to that in arterial plasma except for liver where plasma from portal vein (main inflow) was used (see Materials and Methods section).

${ }^{2}$ By ANOVA with sheep treated as a random effect and comparisons within columns as fixed effects, 18 residual degrees of freedom. Values in same columns, but with unlike superscripts (a-d) are different $(P$ $<0.01$ ), by posthoc $t$-test.

${ }^{3}$ By ANOVA with animals as random effects and based on digestive tract tissues only (i.e., plasma, liver and kidney excluded) as fixed effects, 9 residual degrees of freedom. Values in this column with unlike superscripts (A, B) are different $(P<0.01)$.

sis. The model predicted that, at 90 min postdosing, synthesis of Met from HMTBA within the tissues of the digestive tract $(1.94 \mu \mathrm{mol} / \mathrm{min})$ was equivalent to $24 \%$ of the Met absorbed directly from the lumen $(8 \mu \mathrm{mol} /$ min, Figure 4). The Met synthesized in situ was then partitioned between export into plasma (43\%) and use for tissue protein synthesis within the cell (57\%). If this partition between Met used for protein synthesis and that exported is assumed constant for animals that are fed frequently, then the amount of HMBTA converted to Met within the digestive tract tissues can be estimated from the net $\left[{ }^{13} \mathrm{C}\right]$ Met exchange across the PDV (average $214 \mu \mathrm{mol}$; from Table 2 ) over the $6 \mathrm{~h}$ of study divided by the fraction absorbed (0.43); i.e., $499 \mu \mathrm{mol}$. This increases by $5.4 \%$ (range 1.9 to $7.5 \%$ ), the amount of the dose available in anabolic form to the animal, or equivalent to adding $46 \%$ to the HMTBA absorbed directly. In addition, Met synthesized from HMTBA elsewhere in the body was used to support protein synthesis within the digestive tract, with $1.16 \mu \mathrm{mol} / \mathrm{min}$ entering from the arterial circulation (from inward transport into the cell of $17.46 \mu \mathrm{mol} / \mathrm{min}$ and arterial $\left[1-{ }^{13} \mathrm{C}\right] \mathrm{Met}$ enrichment of $6.7 \mathrm{mpe}$ ). Although this would increase the Met from HMTBA available to the digestive tract tissues by a further $60 \%$, this does not represent an additional source of HMTBA to the animal, unlike the calculations above. 




Figure 4. Model values for conversion of DL-2-hydroxy-4-methylthiobutanoic acid (HMTBA) to Met in tissues of the ovine digestive tract 90 min postdosing and subsequent movements of absorbed, synthesized, and transported Met (all values $\mu$ mol/min). Calculations are based on a combination of data from Experiment 2 and the terminal study. The model is based on the approach described in the Appendix (see Figure 5). The A and V represent arterial and venous plasma inflow and outflow, respectively, across the portal drained viscera. Shown in italics is the amount of Met synthesized from HMTBA in situ and how this is distributed to support intracellular protein synthesis or is exported to the venous outflow. Rectangular boxes represent net inputs and outputs. Absorption represents Met absorbed from the gut lumen (diet plus that from bacterial protein), and Net Met equals numerically absorbed Met plus Met from HMTBA synthesized within the digestive tract tissues. The amount of Met from HMTBA used to support intracellular protein synthesis spares Met from other sources (inward transport or protein degradation) that then contributes to increase Net Met by $24 \%$ more than is absorbed from the lumen.

\section{DISCUSSION}

\section{Absorption of HMTBA}

Until recently, absorption of HMTBA was usually assessed indirectly from changes in plasma Met (Koenig et al., 1999). In comparison with equimolar amounts of commercial forms of DL-Met, changes in plasma Met concentration from HMTBA conversion were more rapid, but had a smaller area under the curve (VázquezAñón et al., 2001b). The reason for this became clear recently with the introduction of more sensitive analytical techniques to quantify plasma HMTBA concentrations (Wester et al., 2006) and the use of stable-isotope labeled HMTBA to determine rates and sites of conversion to Met (Lobley et al., 2006). Previously it had been assumed, based on studies in chickens (Wang et al., 2001), that most of absorbed HMTBA is removed by the liver and converted there to Met, that is then returned to the plasma. The technical advances showed that this concept does not hold for lambs (Wester et al., 2006) or dairy cows (Lapierre et al., 2002). Rather, 65 to $75 \%$ of absorbed HMTBA passes beyond the liver for subsequent metabolism by peripheral tissues (Wester et al., 2006) where the HMTBA is then converted into Met for use in situ (Lobley et al., 2006). Most of the synthesized Met is retained to support tissue protein synthesis with little returned to the plasma. As a consequence, only a small increase in plasma Met is observed (Lobley et al., 2006; current study) even when substantial synthesis from HMTBA occurs.
The conversion of HMTBA to Met is aided by the relatively long half-life of HMTBA in the body, on average $76 \mathrm{~min}$ in the current ovine study and similar in dairy cows (H. Lapierre, M. Vázquez-Añón, and G. E. Lobley, unpublished data). This allows a long exposure for enzymatic conversion to Met, but also means that catabolism of HMTBA, the other fate that contributes to clearance from the body, is relatively slow. In comparison, the half-life of Met is much shorter, approximately $3 \mathrm{~min}$ in sheep under similar conditions (Holtrop et al., 2004) and in dairy cows, the metabolic fate of any absorbed Met will be fully partitioned between oxidation and use for milk protein output within a 15-min time window (Lobley and Lapierre, 2003). In contrast, absorbed HMTBA will be available for synthesis to Met over $5 \mathrm{~h}$, albeit at steadily declining amounts. These differences in half-life relate partly to their fractional extractions by the liver ( 0.13 vs. 0.04 for Met and HMTBA, respectively; Lobley et al., 2001, 2006), the main site of oxidation for Met (Benevenga et al., 1983; Lobley and Lapierre, 2003) and HMTBA (Dupuis et al., 1989) and partly to the fact that a larger equivalent fraction of the absorbed Met is removed because the total inflow to the liver is substantially increased by Met arising as endogenous release from protein degradation (Lobley and Lapierre, 2003).

Previous direct measurements have shown that $87 \%$ of HMTBA infused into the abomasum of sheep is recovered at the portal vein (Lobley et al., 2006). What has been contentious, however, is how much of an oral dose 
survives through the rumen. Measures of rumen degradability in vivo of HMTBA have varied widely (50 to 99\%; Jones et al., 1988; Koenig et al., 1999) and flows to the omasum of less than $6 \%$ have also been recorded (Noftsger et al., 2005). Such measures do not allow for conversion of HMTBA to Met within the rumen, as observed in the current study, or for ruminal and omasal absorption of HMTBA, as reported in vitro (McCollum et al., 2000). The current study, using the much more sensitive isotope dilution approach, yielded direct measures of absorption for the 8 sheep of 7 to $22 \%$. The reasons for this considerable variation between animals offered the same amount of feed is unclear, but liquid passage rate (the inverse of retention time) through the rumen may be critical. For example, studies in dairy cows have shown that when the fractional outflow of liquid from the rumen increased from 0.075 to $0.15 / \mathrm{h}$, then ruminal escape of HMTBA improved from less than $20 \%$ to more than 50\% (Vázquez-Añón et al., 2001c). This was supported by observations with continuous culture fermenters where higher liquid outflow rates did not alter the fractional rate of microbial degradation of HMTBA, but did elevate the amount present in the effluent (Vázquez-Añón et al., 2001a). In the current study, sheep were offered feed either twice daily or as hourly portions. The latter will lead to more consistent rates of passage (Dixon and Milligan, 1985), but lower than in the period immediately following a main meal, when the liquid outflow rate can more than double (Okine et al., 1989). The liquid outflow rate was not determined in the current study, but based on feed composition and amount, values of less than $4 \% / \mathrm{h}$ might be expected (Rodríguez et al., 2000). At such low outflow rates, increased HMTBA degradation by rumen microorganisms (Patterson and Kung, 1988) and lower net absorption would be predicted (Vázquez-Añón et al., 2001c). Interestingly, the individual lambs in Experiment 2 with the highest and lowest liquid intakes also gave the best and worst net absorption of HMTBA, respectively.

Clearly, in terms of assessing how much HMTBA becomes available to the animal, new methodologies are necessary and the sensitive analytical techniques developed for this and companion studies (Wester et al., 2006) provide the basis for novel approaches. First, the current study shows clearly that loss of HMTBA from the plasma, either through conversion to Met or catabolism, follows first order kinetics. If this is coupled with knowledge of HMTBA within body water then total flows (as either absorption or metabolism) through the animal can be estimated. In the chicken, HMTBA transport is mainly by diffusion (Dibner et al., 1988) although $\mathrm{H}^{+}$-dependent transport also occurs (Maenz and Engele-Schaan, 1996). Similarly, in both the ovine rumen and omasum, nonsaturable processes (such as diffusion or paracellular transport) are major contributors to HMTBA transport. Such processes would lead to similar HMTBA concentrations in body water pools and, in practice, for many tissues beyond the digestive tract, intracellular HMTBA concentrations are not significantly different from plasma (Lobley et al., 2006). These findings and assumptions allowed development of a simple model based on the kinetics of plasma HMTBA concentrations. This gave reasonable agreement when tested against direct measures of absorption. If this simple approach is adopted in future studies with HMTBA (or derivatives) then good estimates of availability will be obtained and perhaps this will help resolve many of the uncertainties and controversies that currently surround HMTBA as a potential Met supplement for ruminants.

\section{Digestive Tract Metabolism of HMTBA}

The current studies indicate that less than $30 \%$ of the oral dose was absorbed by the lambs as HMTBA and, therefore, the majority has been either oxidized or converted to other products. In part, this must relate to events within the forestomachs because of the high proportion (87\%) of doses supplied directly into the abomasum subsequently absorbed into the portal vein (Lobley et al., 2006). The ability of rumen microorganisms to metabolize HMTBA is well established (Belasco, 1972; Patterson and Kung, 1988), but disappearance within the rumen may be via several routes, including incorporation into microbial products and conversion to other intermediary metabolites that may be later absorbed. In the current study, degradation involving loss of the carboxyl-C as $\mathrm{CO}_{2}$ and recovered in the portal vein was monitored, but over a 6 -h period this accounted for less than $25 \%$ of the dose given. Indeed, in total only 28 to $45 \%$ of the ${ }^{13} \mathrm{C}$ supplied in the dose was recovered in the portal vein as either HMTBA or $\mathrm{CO}_{2}$. This strengthens the case for conversion to other metabolites within the ruminal fluid. One such metabolite might be Met and certainly the ruminal fluid contained ${ }^{13} \mathrm{C}$-enriched free Met at $90 \mathrm{~min}$ postdose. Some of this Met may have been used to support microbial protein synthesis, but this was not tested in the current study. A further 10 to $20 \%$ of the oral dose was still present as free HMTBA within the ruminal fluid after $90 \mathrm{~min}$. This, in conjunction with the amount absorbed, suggests a minimum half-life for ruminal degradation between 7 to $30 \mathrm{~min}$ and this again emphasizes the importance of ruminal liquid outflow rates in determining HMTBA availability to the small intestine and, therefore, to the animal. 
Although HMTBA has been shown to be transported across both ruminal and omasal epithelia in vitro, it is unlikely that the rumen is the main site of HMTBA absorption in vivo for several reasons. First, following an oral dose, the rumen becomes the primary pool and direct absorption from this would follow first-order kinetics. In practice, the absorption curves shown in Figure 1 fitted well with a model simulation based on absorption from a secondary pool (data not shown). Second, the concentration of HMTBA in ruminal tissue was less than $10 \%$ of that in the rumen liquor, not a result expected close to the primary pool site for a diffusible substrate. Furthermore, the concentrations of HMTBA in remaining tissues of the digestive tract were higher at 90 min postdose than in either rumen epithelia or plasma. This again suggests that liquid digesta flow beyond the rumen is a major route of HMTBA delivery to the animal.

\section{Conversion to Met in Digestive Tract Tissues}

2-Hydroxy-4-methylthiobutanoic acid may also be converted to Met within the tissues of the digestive tract during the absorption process and this would increase the net availability to the animal. The enzymes responsible for conversion of both the D- and L-isomers of HMTBA to oxo-Met show wide distribution across tissues in poultry (Dibner and Knight, 1984), although they differ in cellular localization (D-hydroxy acid dehydrogenase is present in mitochondria, and the L- $\alpha$-hydroxy acid oxidase is located within peroxisomes). Such cellular distribution probably also exists for mammals and, in sheep, total enzyme activity (i.e., the ability to convert both $\mathrm{D}$ and $\mathrm{L}$ isomers) is similar between rumen, omasum, liver, and kidney tissue (McCollum et al., 2000). In both rumen and omasum (as well as kidney), activity in vitro of D-hydroxy acid dehydrogenase exceeds that of $\mathrm{L}$ - $\alpha$-hydroxy acid oxidase (McCollum et al., 2000) and this is compatible with the smaller proportions of the D-isomer found within the cells of these tissues (and other parts of the digestive tract) in the current study in vivo.

Evidence that these 2 enzymes play an important role in vivo is shown by the increases in the ratio of free $\left[{ }^{13} \mathrm{C}\right]:\left[{ }^{2} \mathrm{H}_{3}\right]$ Met enrichments within the various tissues of the digestive tract and across the PDV. Such ratios help identify the sites of Met synthesis from HMTBA, and the data suggest that the various parts of the digestive tract may differ in this ability. For example, Met synthesis de novo appeared to be greater for the omasum compared with the duodenum (12 vs. $8 \%$ ), assessed relative to the Met that enters the cell from the plasma ( 88 vs. $92 \%$ ). This finding is only relevant at 90 min postdosing, however, and may reflect the amount of HMTBA available within the lumen of the different sections of the digestive tract at that time, rather than difference in the metabolic capacity of conversion by the tissues. Indeed, an earlier study had shown, during continuous infusion of HMTBA into the abomasum, that rates of conversion to Met were similar between various parts of the small intestine (Lobley et al., 2006). The magnitude of Met synthesis from HMTBA by the digestive tract tissues was assessed based on data from the second 4 lambs applied to an arteriovenous model. This predicted substantial Met production, equivalent to $24 \%$ of the Met absorbed from the diet. Of this, approximately half was used to support protein synthesis within the digestive tract tissues and this would spare Met from both dietary and endogenous sources. The digestive tract tissues were also able to utilize Met synthesized from HMTBA elsewhere in the body, mainly the kidney (Lobley et al., 2006), and this again would spare dietary Met. Conversion of HMBTA to Met within the digestive tract tissues during the absorptive process should properly be added to the estimation of HMBTA available to the animal, as should any converted to Met within the rumen and then used by the rumen microbes to support their protein synthesis. The latter process was not quantified in this study, but the estimates of Met synthesis within the digestive tract tissues involves conversion of a further $5 \%$ of the dose to an anabolic product under the current experimental conditions. Thus, for these lambs HMTBA either absorbed directly or converted to Met within the tissues of the digestive tract represented 10.6 to $27.9 \%$ of the dose. What is not known, however, is whether the conversion of HMTBA to Met within the digestive tract is dose dependent or represents a fixed value linked to the enzyme capacity within the tissues.

Interestingly, the data indicate that Met synthesized from HMTBA within the digestive tract tissues was used in preference to that available from plasma inflow. This is similar to the situation for other tissues (Lobley et al., 2006). In terms of advantage to the animal, this would yield an energy saving through use of passive diffusion of HMTBA (McCollum et al., 2000) rather than involvement of active transport of Met (Christensen, 1990). Although rates of conversion of HMTBA to Met in the digestive tract tissues do not match those in the kidney, the export capacity seems to be greater than for liver (Lobley et al., 2006) and, as such, can provide an important contribution to Met economy of the ruminant.

\section{CONCLUSIONS}

When made available to the tissues, HMTBA provides an effective precursor for synthesis of Met in rumi- 
nants. Not all of an oral dose is available to the animal, however, and a number of factors determine the absolute amount available. These factors include retention time (the inverse of liquid outflow rate) within the rumen. Besides absorption of HMTBA directly, the tissues of the digestive tract also synthesize Met from HMTBA, and this is then available for absorption or to support tissue protein synthesis with consequent sparing of dietary Met. Through a novel approach it is now possible to estimate HMTBA availability to the animal through analysis of plasma samples and this will help determine husbandry conditions where most effective use can be made of this feed additive for ruminants.

\section{ACKNOWLEDGMENTS}

The technical expertise of Graham Calder for the various mass spectrometry analyses is gratefully acknowledged.

\section{REFERENCES}

Belasco, I. J. 1972. Stability of methionine hydroxy analog in rumen fluid and its conversion in vitro to methionine by calf liver and kidney. J. Dairy Sci. 55:353-357.

Benevenga, N. J., B. C. Radcliffe, and A. R. Egan. 1983. Tissue metabolism of methionine in sheep. Aust. J. Biol. Sci. 36:475-485.

Biolo, G., R. Y. D. Fleming, S. P. Maggi, and R. R. Wolfe. 1995. Transmembrane transport and intracellular kinetics of amino acids in human skeletal muscle. Am. J. Physiol. 268:E75-E84.

Calder, A. G., K. E. Garden, S. E. Anderson, and G. E. Lobley. 1999. Quantitation of blood and plasma amino acids using isotope dilution electron impact gas chromatography/mass spectrometry with $\mathrm{U}^{13} \mathrm{C}$ amino acids as internal standards. Rapid Commun. Mass Spectrom. 13:2080-2083.

Christensen, H. N. 1990. Role of amino acid transport and countertransport in nutrition and metabolism. Physiol. Rev. 70:43-77.

Dibner, J. J., and C. D. Knight. 1984. Conversion of 2-hydroxy-4(methylthio)butanoic acid to L-methionine in the chick: A stereospecific pathway. J. Nutr. 114:1716-1723.

Dibner, J. J., C. D. Knight, R. A. Swick, and F. J. Ivey. 1988. Absorption of 14C-2-hydroxy-4-(methylthio)butanoic acid (Alimet) from the hindgut of the broiler chick. Poult. Sci. 67:1314-1321.

Dixon, R. M., and L. P. Milligan. 1985. Removal of digesta components from the rumen of steers determined by sieving techniques and fluid, particulate and microbial markers. Br. J. Nutr. 53:347-362.

Dupuis, L., C. L. Saunderson, A. Puigserver, and P. Brachet. 1989. Oxidation of methionine and 2-hydroxy-4-methylthiobutanoic acid stereoisomers in chicken tissues. Br. J. Nutr. 62:63-75.

Holtrop, G., H. Lapierre, and G. E. Lobley. 2004. Modelling transport of amino acids into the red blood cells of sheep. J. Agric. Sci. 142:577-588.

Jones, B. A., O. E. Mohamed, R. W. Prange, and L. D. Satter. 1988. Degradation of methionine hydroxy analog in the rumen of lactating cows. J. Dairy Sci. 71:525-529.

Koenig, K. M., L. M. Rode, C. D. Knight, and P. R. McCullough. 1999. Ruminal escape, gastrointestinal absorption, and response of serum methionine to supplementation of liquid methionine hydroxy analog in dairy cows. J. Dairy Sci. 82:355-361.

Lapierre, H., J. J. Dibner, M. Vazquez-Anon, D. Parker, P. Dubreuil, M. Babkine, G. Zuur, and G. E. Lobley. 2002. Use of 2-hydroxy4-[methylthio]-butanoic acid (HMB) by lactating dairy cows. J. Dairy Sci. 85(Suppl. 1):286. (Abstr.)

Lobley, G. E., D. M. Bremner, and D. S. Brown. 2001. Response in hepatic removal of amino acids by the sheep to short-term infusion of varied amounts of an amino acid mixture into the mesenteric vein. Br. J. Nutr. 85:689-698.

Lobley, G. E., A. Connell, M. A. Lomax, D. S. Brown, E. Milne, A. G. Calder, and D. A. H. Farningham. 1995. Hepatic detoxification of ammonia in the ovine liver: Possible consequences for amino acid catabolism. Br. J. Nutr. 73:667-685.

Lobley, G. E., A. Connell, and D. Revell. 1996. The importance of transmethylation reactions to methionine metabolism in sheep: Effects of supplementation with creatine and choline. Br. J. Nutr. 75:47-56.

Lobley, G. E., and H. Lapierre. 2003. Post-absorptive metabolism of amino acids. Pages 737-756 in Progress in Research on Energy and Protein Metabolism. W. B. Souffrant, and C. C. Metges, ed. EAAP publication no. 109. Wageningen, The Netherlands.

Lobley, G. E., X. Shen, G. Le, D. M. Bremner, E. Milne, A. G. Calder, S. A. Anderson, and N. Dennison. 2003. Oxidation of essential amino acids by the ovine gastro-intestinal tract. Br. J. Nutr. 89:1-14.

Lobley, G. E., T. J. Wester, A. G. Calder, J. J. Dibner, D. S. Parker, and M. Vázquez-Añón. 2006. Absorption of 2-hydroxy-4-methylthiobutanoic acid and conversion to methionine in lambs. J. Dairy Sci. 89:1072-1080.

Maenz, D. D., and C. M. Engele-Schaan. 1996. Methionine and 2hydroxy-4-methylthiobutanoic acid are transported by distinct $\mathrm{Na}$-dependent and $\mathrm{H}+-$ dependent systems in the brush border membrane of the chick intestinal epithelium. J. Nutr. 126:529536.

McCollum, M. Q., M. Vásquez-Añón, J. J. Dibner, and K. E. Webb, Jr. 2000. Absorption of 2-hydroxy-4-(methylthio)butanoic acid by isolated sheep ruminal and omasal epithelia. J. Anim. Sci. 78:1078-1083.

Noftsger, S., N. R. St-Pierre, and J. T. Sylvester. 2005. Determination of rumen degradability and ruminal effects of three sources of methionine in lactating cows. J. Dairy Sci. 88:223-227.

Okine, E. K., G. W. Mathison, and R. T. Hardin. 1989. Relations between passage rates of rumen fluid and particulate matter and foam production in rumen contents of cattle fed on different diets ad lib. Br. J. Nutr. 61:387-395.

Patterson, J. A., and L. Kung, Jr. 1988. Metabolism of DL-methionine and methionine-analogs by rumen microorganisms. J. Dairy Sci. 71:3292-3301.

Read, W. W., M. Read, M. J. Rennie, R. C. Griggs, and D. Halliday. 1984. Preparation of CO2 from blood and protein-bound amino acid carboxyl groups for quantitation of 13C-isotope enrichments. Biomed. Mass Spectrom. 15:467-472.

Rodríguez, C. A., J. González, M. R. Alvir, J. L. Repetto, C. Centeno, and F. Lamrani. 2000. Composition of bacteria harvested from the liquid and solid fractions of the rumen of sheep as influenced by feed intake. Br. J. Nutr. 84:369-376.

Sigaard-Andersen, O., P. D. Wimberley, N. Fogh-Andersen, and I. H. Gothgen. 1988. Measured and derived quantities with modern $\mathrm{pH}$ and blood gas equipment: Calculation algorithms with 54 equations. Scand. J. Clin. Lab. Invest. 48(Suppl. 189):7-15.

Vázquez-Añón, M., T. Cassidy, P. McCullough, and G. A. Varga. 2001a. Effects of alimet on nutrient digestibility, bacterial protein synthesis, and ruminal disappearance during continuous culture. J. Dairy Sci. 84:159-166.

Vázquez-Añón, M., D. Parker, and J. J. Dibner. 2001b. Differential response of free plasma D- and L-methionine in cows fed different rumen protected methionine sources. J. Dairy Sci. 79(Suppl. 1):284. (Abstr.)

Vázquez-Añón, M., D. Parker, K. M. Koenig, and L. M. Rode. 2001c. Alimet degradation in the rumen and availability to the animal. Pages 1-14 in Proc. Southwest Nutr. Manag. Conf. Univ. Arizona, Tuscon.

Wang, S., W. Bottje, Z. Song, K. Beers, M. Vázquez-Añón, and J. J. Dibner. 2001. Uptake of DL-2-hydroxy-4-(methylthio)butanoic acid (HMB) in the broiler liver in vivo. Poult. Sci. 80:1619-1624.

Wester, T. J., M. Vázquez-Añón, J. J. Dibner, D. S. Parker, A. G. Calder, and G. E. Lobley. 2006. Hepatic metabolism of 2-hydroxy4-methylthiobutanoic acid in growing lambs. J. Dairy Sci. 89:1062-1071. 


\section{APPENDIX}

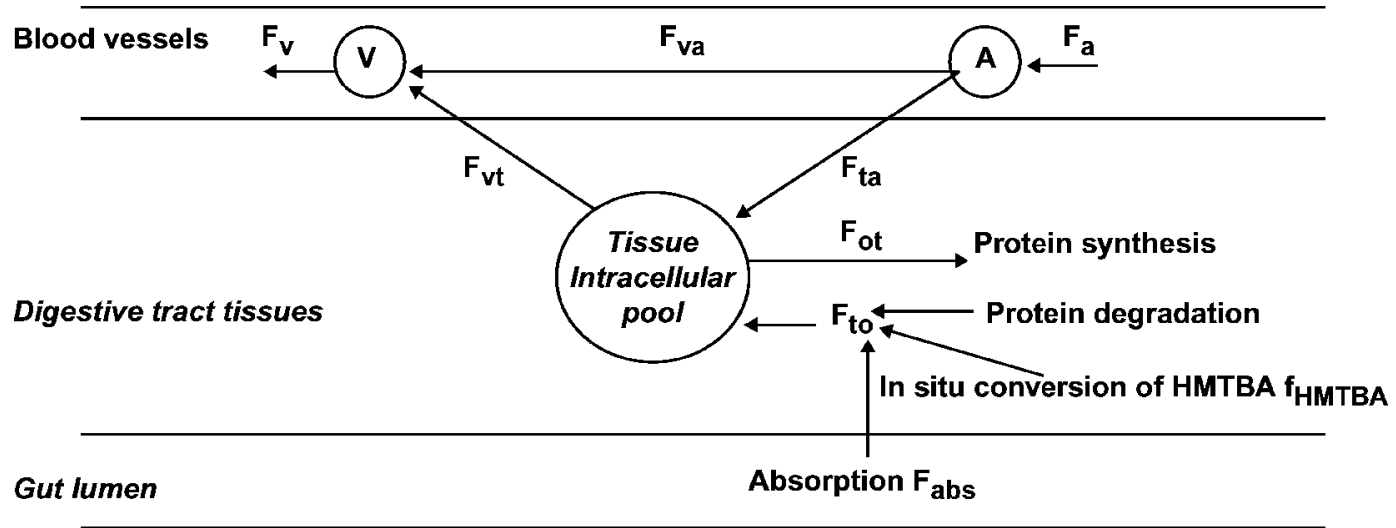

Figure 5. Model extended from Biolo et al. (1995) to allow measurement of metabolite inflow, bypass and utilization across the portal drained viscera of Met. Definition of symbols and abbreviations are detailed in the text of the Appendix.

A model was developed to quantify the metabolism of Met and HMTBA across the digestive tract, based on data obtained from arteriovenous differences and use of stable isotopes. It was assumed that all intracellular events flow through a common pool and that the intracellular enrichment of the digestive tract is equal to the average of the enrichments measured in tissues from the various tract sections. It was further assumed that both labeled and unlabeled species of Met were treated similarly by the body and that the activity of the Met cycle, involving conversion of Met to homocysteine and back to Met, is low in these tissues. Based on these assumptions the following model, presented in its general form in Figure 5, was developed:

Step 1: Inward and outward transport, arterial bypass, protein synthesis, and protein degradation (including synthesis de novo) were calculated, based on the $\left[{ }^{2} \mathrm{H}_{3}\right]$ Met enrichments (based on Biolo et al., 1995). This model was then extended (steps 2 and 3 below) to allow for conversion of HMTBA to Met by the digestive tract tissues.

Step 2: Combining the arterial $\left[1-{ }^{13} \mathrm{C}\right]$ Met enrichments with the various flows obtained in step 1, estimation is allowed of the various $\left[1-{ }^{13} \mathrm{C}\right]$ Met flows through the tissue in the absence of any conversion of HMTBA by the digestive tract.

Step 3: The tissue $\left[1-{ }^{13} \mathrm{C}\right]$ Met enrichment, combined with the various flows obtained in step 1, gives the observed amount of HMTBA-derived Met that is passing through the tissue. The contribution of HMTBAderived Met converted in situ is then obtained from the difference between the observed $\left[1-{ }^{13} \mathrm{C}\right]$ Met flows and the estimated $\left[1-{ }^{13} \mathrm{C}\right]$ Met flows in the absence of such conversion (step 2).
The model also assumes that all $\left[1-{ }^{13} \mathrm{C}\right]$ Met derived across the gut arises from tissue metabolism and that the contribution from bacteria is negligible. Although Met can be synthesized from HMTBA and used for bacterial protein synthesis, little of this is likely to reach the small intestine within 90 min postdose.

\section{Calculation of Met Flows}

Let $\mathrm{F}$ and $\mathrm{E}$ be the metabolite flows (concentration $\times$ plasma flow) and enrichments, respectively. The term $\mathrm{F}_{\mathrm{yx}}$ represents the flow to pool $\mathrm{y}$ from pool $\mathrm{x}$. The subscripts $\mathrm{a}, \mathrm{v}$, and $\mathrm{t}$ refer to the arterial, venous, and tissue intracellular pools of free Met, respectively, and o refers to Met from other sources (protein-bound Met, Met absorbed from the diet, and Met obtained from HMTBA conversion); $F_{a}$ and $F_{v}$ are the arterial inflows and venous outflows of Met, respectively, and are known (Met concentration multiplied by plasma flow). The net Met flow (i.e., apparent absorption) is obtained from $F_{v}-F_{a}$. The steady state equations of free Met for the arterial, venous, and tissue intracellular pools, respectively, are given by

$$
\begin{aligned}
& \mathrm{F}_{\mathrm{a}}-\mathrm{F}_{\mathrm{va}}-\mathrm{F}_{\mathrm{ta}}=0 ; \\
& \mathrm{F}_{\mathrm{va}}+\mathrm{F}_{\mathrm{vt}}-\mathrm{F}_{\mathrm{v}}=0 \\
& \mathrm{~F}_{\mathrm{ta}}+\mathrm{F}_{\mathrm{to}}-\mathrm{F}_{\mathrm{ot}}-\mathrm{F}_{\mathrm{vt}}=0 .
\end{aligned}
$$

For $\left[{ }^{2} \mathrm{H}_{3}\right]$ Met, the steady-state equations for the venous pool and tissue intracellular pool are given by

$$
\begin{aligned}
& E_{a(d)} \times F_{v a}+E_{t(d)} \times F_{v t}-E_{v(d)} \times F_{v}=0 \\
& E_{a(d)} \times F_{t a}-E_{t(d)}-F_{o t}-E_{t(d)} \times F_{v t}=0
\end{aligned}
$$


where $\mathrm{E}_{\mathrm{a}(\mathrm{d})}, \mathrm{E}_{\mathrm{t}(\mathrm{d})}$ and $\mathrm{E}_{\mathrm{v}(\mathrm{d})}$ are the arterial, tissue intracellular, and venous enrichments of deuterated $\left[{ }^{2} \mathrm{H}_{3}\right]$ Met, respectively. Combining [1] with [2] gives:

$$
F_{v t}=\frac{E_{a(d)}-E_{v(d)}}{E_{a(d)}-E_{t(d)}} \times F_{v} .
$$

Then the remaining flows are obtained from

$$
\begin{aligned}
& \mathrm{F}_{\mathrm{va}}=\mathrm{F}_{\mathrm{v}}-\mathrm{F}_{\mathrm{vt}} \\
& \mathrm{F}_{\mathrm{ta}}=\mathrm{F}_{\mathrm{a}}-\mathrm{F}_{\mathrm{va}} \\
& \mathrm{F}_{\mathrm{ot}}=\frac{\mathrm{E}_{\mathrm{a}(\mathrm{d})} \times \mathrm{F}_{\mathrm{ta}}-\mathrm{E}_{\mathrm{t}(\mathrm{d})} \times \mathrm{F}_{\mathrm{vt}}}{\mathrm{E}_{\mathrm{t}(\mathrm{d})}} \\
& \mathrm{F}_{\mathrm{to}}=\mathrm{F}_{\mathrm{ot}}+\mathrm{F}_{\mathrm{vt}}-\mathrm{F}_{\mathrm{ta}} .
\end{aligned}
$$

Note that, at this stage, $\mathrm{F}_{\mathrm{to}_{0}}$ is a composite of intracellular free Met appearance from proteolysis, absorption, and HMTBA conversion.

\section{Derivation of HMTBA-Derived $\left[{ }^{13} \mathrm{C}\right]$ Met Flows}

In the absence of HMTBA conversion across the digestive tract, the ratio of $\left[{ }^{13} \mathrm{C}\right]$ to $\left[{ }^{2} \mathrm{H}_{3}\right]$ Met enrichments would be the same for the arterial, venous, and tissue intracellular pools. Let the ratio of $\left[{ }^{13} \mathrm{C}\right]:\left[{ }^{2} \mathrm{H}_{3}\right]$ Met enrichments in the arterial blood be denoted by $\mathrm{R}_{\mathrm{a}}$. The $\left[{ }^{13} \mathrm{C}\right]$ Met flows, given the subscript $\mathrm{c}$, from arterial origin are obtained from multiplying the $\left[{ }^{2} \mathrm{H}_{3}\right]$ Met flows by $R_{\mathrm{a}}$. Now, $\mathrm{f}_{\mathrm{vt}(\mathrm{ca})}$ denotes the predicted $\left[{ }^{13} \mathrm{C}\right]$ Met flow, of arterial origin, from the tissue intracellular pool to the venous pool. Then

$$
f_{\mathrm{vt}(\mathrm{ca})}=\mathrm{R}_{\mathrm{a}} \times \mathrm{E}_{\mathrm{t}(\mathrm{d})} \times \mathrm{F}_{\mathrm{vt}} .
$$

The observed total $\left[{ }^{13} \mathrm{C}\right]$ Met flow from the tissue intracellular pool to the venous pool is given by $\mathrm{E}_{\mathrm{t}(\mathrm{c})} \times \mathrm{F}_{\mathrm{vt}}$, where $\mathrm{E}_{\mathrm{t}(\mathrm{c})}$ is the $\left[{ }^{13} \mathrm{C}\right]$ Met enrichment of the tissue intracellular pool. The difference between the predicted and observed flows represents $\left[{ }^{13} \mathrm{C}\right]$ Met derived from conversion of HMTBA $\left(\mathrm{f}_{\mathrm{vt}(\text { HMTBA })}\right)$ :

$$
f_{\mathrm{vt}(\text { HMTBA })}=\mathrm{E}_{\mathrm{t}(\mathrm{c})} \times \mathrm{F}_{\mathrm{vt}}-\mathrm{f}_{\mathrm{vt}(\mathrm{ca})} \text {. }
$$

The $\left[{ }^{13} \mathrm{C}\right]$ Met flows from the tissue intracellular pool to protein synthesis can be divided analogously. Let $\mathrm{f}_{\mathrm{ot}(\mathrm{ca})}$ be the predicted $\left[{ }^{13} \mathrm{C}\right]$ Met flow, from arterial origin:

$$
f_{\text {ot(ca) }}=R_{a} \times E_{t(d)} \times F_{o t} .
$$

The observed total $\left[{ }^{13} \mathrm{C}\right]$ Met flow from the tissue intracellular pool to the protein pool is obtained from $\mathrm{E}_{\mathrm{t}(\mathrm{c})}$ $\times \mathrm{F}_{\text {ot. }}$. Then,

$$
f_{\text {ot(HMTBA })}=E_{t(c)} \times F_{\text {ot }}-f_{\text {ot(ca) }} .
$$

As the only HMTBA-derived $\left[{ }^{13} \mathrm{C}\right]$ Met outflows from the intracellular pool are $f_{\mathrm{vt}(\text { HMTBA) }}$ and $\mathrm{f}_{\text {ot(HMTBA), the }}$ inflow of $\left[{ }^{13} \mathrm{C}\right]$ Met from HMTBA conversion across the gut tissue, $\mathrm{f}_{\mathrm{HMTBA}}$, is given by

$$
f_{\text {HMTBA }}=f_{\text {vt(HMTBA })}+f_{\text {ot(HMTBA })} \text {. }
$$

\section{Separation of $F_{\text {to }}$ into Subcomponents}

$\mathrm{F}_{\text {to }}$ is assumed to be the sum of dietary absorption $\left(\mathrm{F}_{\text {abs }}\right)$, protein breakdown, and HMTBA conversion $\left(f_{\text {HMTBA }}\right)$. Assuming protein breakdown equals protein synthesis, $F_{a b s}$ is given by $F_{a b s}=F_{o t}-f_{\text {HмтвA. }}$.

\section{Effect of Met Cycle Activity}

The above model description assumes that the change in $\left[{ }^{13} \mathrm{C}\right]:\left[\right.$ methyl- $\left.{ }^{2} \mathrm{H}_{3}\right]$ Met only occurs due to synthesis of $\left[1-{ }^{13} \mathrm{C}\right]$ Met from HMTBA. If the Met cycle operates in the tissue, however, then the conversion of [methyl$\left.{ }^{2} \mathrm{H}_{3}\right]$ Met to homocysteine and then back to Met will result in the probable loss of the labeled methyl group and thus will increase the ratio as the enrichment of the denominator is reduced. This will lower the true contribution of synthesis of Met in situ from HMTBA. Based on earlier studies in sheep (Lobley et al., 1996) the increase in tissue $\left[{ }^{13} \mathrm{C}\right]:\left[\right.$ methyl- $\left.{ }^{2} \mathrm{H}_{3}\right]$ Met compared with plasma is less than 1.5-much smaller than the ratio changes of 2.3 to 3.2 observed in the current animals. Thus, substantial synthesis of Met from HMTBA must occur within the tissues of the digestive tract. 